\title{
Aspek Fundamental Teknikal dan Makroekonomi pada Sektor Energi di Bursa Efek Indonesia Periode 2015 - 2019
}

\author{
Muhamad Bagas Prastio ${ }^{1}$, Muhani ${ }^{1}$, Irma Setyawati ${ }^{1, *}$ \\ ${ }^{1}$ Fakultas Ekonomi dan Bisnis; Universitas Nasional; Jl. Sawo Manila Pasar Minggu Jakarta; \\ Telp. 021 - 7806700; e-mail: mbagasprastio2018@student.unas.ac.id, \\ muhani@civitas.unas.ac.id, irmasetyawati@civitas.unas.ac.id \\ * Korespondensi: e-mail: irmasetyawati@civitas.unas.ac.id \\ Submitted: 28/12/2021; Revised: 05/01/2022; Accepted: 10/01/2022; Published: $31 / 01 / 2022$
}

\begin{abstract}
The purpose of this study is to analyze stock price using fundamental, technical and macroeconomic aspects. The research data was obtained from the Indonesia Stock Exchange for Energy Sector Companies, 2015 - 2019. Multiple regression equations were used to determine the effect between stock prices and fundamental, technical and macroeconomic aspects. Fundamental aspects include Earning Per Share, Return on Equity, Current Ratio and Debt to Equity Ratio. The technical aspect is seen from the trend of stock movements, while the macroeconomic aspect is shown by the interest rates ofr Bank Indonesia Certificates, world oil prices, and foreign exchange rates. The results of the study show that Earning Per Share and stock price movements have a positive and significant effect on stock prices, Return on Equity, Current Ratio, Debt to Equity Ratio, and the Rupiah Exchange rate have a negative and insignificant effect, while the interest rate ofr Bank Indonesia Certificates and world oil price have a negative and significant effect. From this research, it is hoped that it will be useful for academics and the public to pay attention to aspects that affect stock prices in investing in the shares of a company. Besides that, it can also be useful for companies in determining strategies to increase stock prices.
\end{abstract}

Keywords: Fundamental Aspect, Macroeconomics Aspect, Stock Prices, Technical Aspect, world oil price

\begin{abstract}
Abstrak
Tujuan penelitian ini untuk menganalisis harga saham dengan menggunakan aspek fundamental, teknikal dan makro ekonomi. Data penelitian diperoleh dari Bursa Efek Indonesia pada perusahaan sektor energi, periode 2015-2019. Persamaan regresi berganda digunakan untuk menentukan pengaruh antara harga saham and aspek fundamental, teknikal dan makro ekonomi. Aspek fundamental meliputi Earning Per Share, Return on Equity, Current Ratio dan Debt to Equity Ratio. Aspek teknikal dilihat dari trend pergerakan saham, sedangkan aspek makro ekonomi ditunjukkan oleh suku bunga Sertifikat Bank Indonesia, harga minyak dunia, dan kurs valuta asing. Hasil penelitian ini adalah Earning Per Share dan tren pergerakan harga saham berpengaruh positif dan signifikan terhadap harga saham, variabel Return on Equity, Current Ratio, Debt to Equity Ratio, kurs rupiah terhadap dolar berpengaruh negatif dan tidak signifikan, sedangkan variabel suku bunga Sertifikat Bank Indonesia dan harga minyak dunia berpengaruh negatif dan signifikan. Dari penelitian ini diharapkan bermanfaat bagi akademisi dan khalayak masyarakat untuk memperhatikan aspek-aspek yang mempengaruhi harga saham dalam melakukan investasi terhadap saham suatu perusahaan. Di samping itu juga dapat bermanfaat bagi perusahaan dalam menetapkan stategi untuk meningkatkan harga saham.
\end{abstract}


Kata kunci: Aspek Fundamental, Aspek Macroekonomi, Aspek Teknikal, Harga Minyak Dunia, Harga Saham

\section{Pendahuluan}

Tahun 2020 diawali dengan peristiwa pandemik COVID19 yang menyebabkan perlambatan pertumbuhan ekonomi dunia dan dipicu oleh krisis keuangan global akibat terjadinya resesi di semua negara selama pandemik. Hampir semua harga komoditas mengalami kenaikan, demikian juga harga hasil tambang dan minyak. Selama pandemi COVID19, harga minyak mencapai harga $\$ 65,65$ per barel, yang merupakan harga tertinggi pada saat itu. Selain itu, suku bunga dan nilai tukar dolar AS mengalami peningkatkan akibat pandemi COVID19. Nilai tukar dolar AS mencapai Rp 16.824,71, yang merupakan nilai tertinggi pada tahun 2020. Kenaikan nilai tukar tersebut diiringi dengan penurunan suku bunga dari 1\% menjadi 3.75\% pada akhir tahun 2020 (Statistik Bank Indonesia, 2020). Demikian pula aktivitas pergerakan IHSG dan serta sektor-sektor di dalamnya mengalami perubahan (Setyawati, I., Sufyati, H. S., Kasim, M. Y., Meini, Z., \& Hardini, 2020).

Harga saham sektor pertambangan mengalami fluktuasi. Pada penutupan tahun 2015, rata-rata harga saham sektor pertambangan berada di posisi - Rp 557.927 dan akhir tahun 2016 mencatatkan kenaikan harga yang signifikan sebesar Rp 573.63, dan turun pada harga Rp 209.293 di akhir tahun 2017 (Statistik Pasar Modal, 2018). Hal ini berbanding lurus dengan perkembangan Indeks Harga Saham Gabungan (IHSG), di mana saham-saham sektor pertambangan berfluktuasi searah dengan fluktuasi IHSG. Tabel 1 menyajikan perkembangan IHSG, diikuti oleh indeks sektor-sektor dalam pasar modal di Indonesia. Sektor pertambangan merupakan salah satu sektor perusahaan yang terdampak terhadap pandemi COVID19. Hal tersebut ditandain dengan harga saham sektor pertambangan mengalami penurunan sekitar 12,38\% pada akhir tahun 2019 dibandingkan tahun 2018.

Tabel 1. Indeks Sektoral di Bursa Efek Indonesia dan IHSG, Periode 2015-2019

\begin{tabular}{|c|c|c|c|c|c|}
\hline \multirow[t]{2}{*}{ Sektor } & \multicolumn{5}{|c|}{ Tahun } \\
\hline & 2015 & 2016 & 2017 & 2018 & 2019 \\
\hline $\begin{array}{l}\text { Agraria, } \quad \text { Peternakan } \\
\text { Kehutanan dan Perikanan }\end{array}$ & $-26.87 \%$ & $8.43 \%$ & $-13.30 \%$ & $-3.21 \%$ & $-2.55 \%$ \\
\hline Pertambangan dan Penggalian & $-40.75 \%$ & $70.73 \%$ & $15.11 \%$ & $11.45 \%$ & $-12.38 \%$ \\
\hline Industri Dasar dan Kimia & $-24.98 \%$ & $31.96 \%$ & 28.06 & $24.01 \%$ & $14.44 \%$ \\
\hline Aneka Industri & $-19.11 \%$ & $29.64 \%$ & $0.77 \%$ & $0.96 \%$ & $-12.23 \%$ \\
\hline Barang Konsumsi & $-5.19 \%$ & $12.56 \%$ & $23.11 \%$ & $-10.21 \%$ & -20.11 \\
\hline Properti dan Real Estate & $-6.47 \%$ & $5.47 \%$ & $-4.31 \%$ & $-9.64 \%$ & $12.54 \%$ \\
\hline Transportasi dan Infrastruktur & $-15.42 \%$ & $7.57 \%$ & $12.14 \%$ & $-10.09 \%$ & $6.88 \%$ \\
\hline Keuangan & $-6.10 \%$ & $18.17 \%$ & $40.52 \%$ & $3.05 \%$ & $15.22 \%$ \\
\hline $\begin{array}{l}\text { Perdagangan } \\
\text { Investasi }\end{array}$ & $-3.31 \%$ & $1.31 \%$ & $7.08 \%$ & $-14.94 \%$ & $-1.79 \%$ \\
\hline Manufaktur & $-13.75 \%$ & $18.84 \%$ & $19.83 \%$ & $-1.34 \%$ & $-9.72 \%$ \\
\hline IHSG & $-12.13 \%$ & $15.32 \%$ & $19.99 \%$ & $-2.54 \%$ & $1.70 \%$ \\
\hline
\end{tabular}

Sumber: Statistik Pasar Modal (2021)

Untuk melakukan investasi saham, maka investor perlu melakukan kelayakan investasi. Terdapat tiga analisis yang dapat dipergunakan yaitu analisis fundamental, analisis teknikal dan makroekonomi. Riset investasi adalah langkah yang diambil investor untuk 
memahami prospek suatu proyek investasi mendukung keputusan untuk menerima atau menolak suatu investasi. Penting untuk melakukan riset sebelum memutuskan untuk tidak berinvestasi dalam proyek atau kegiatan yang tidak menguntungkan (Setiawan, 2020).

Analisis fundamental merupakan sebuah cara dalam menganalisis harga saham dengan melibatkan beberapa faktor seperti industri, kondisi perusahaan, dan ekonomi perusahaan untuk mencari berapa besarnya nilai dari sebuah harga saham suatu perusahaan. Analisis fundamental memberikan hasil yang dapat dilihat pada dampak positif dari Earning Per Shares perusahaan yang memberikan nilai yang tinggi, yang berarti saham perusahaan tersebut layak untuk dibeli (Artha, 2014). Pernyataan tersebut didasari pada pengamatan bahwa para investor di bursa yang melakukan diversifikasi dalam melakukan investasi pada sekumpulan saham sebagai upaya memlihi saham mana yang akan dibeli nantinya. Dengan melakukan analisis fundamental, menunjukkan hubungan positif antara harga saham yang layak untuk dibeli dengan hasil dari analisis fundamental tersebut. Ini menunjukkan semakin kuatnya analisis fundamental untuk menunjukkan semakin bagus tidaknya saham itu untuk dibeli (Setyawati, I., Molina, M., Muhani, M., \& Huda, 2021).

Analisis teknikal merupakan jenis analisis lainnya yang dapat dimanfaatkan investor bertujuan menganalisis harga saham. Upaya untuk mengidentifikasi atau memilih patron dan tren harga di pasar keuangan dan mencoba menggunakan pola tersebut disebut analisis teknikal. Dinamika saham berfluktuasi terlalu kuat akibat krisis keuangan 2008. Fenomena tersebut membuktikan bahwa trend harga saham memiliki efek cukup andil kepada harga saham sektor pertanian (Artha, 2014). Analisis fundamental dan teknikal menolong investor dalam menyaring saham perusahaan mana yang akan dibeli pada saat tertentu.

Data makroekonomi sering dianggap signifikan bagi investor yang mencari saham untuk dibeli nanti. Data makroekonomi sering kali mencakup peristiwa yang terjadi di luar perusahaan. Data makroekonomi, seperti perubahan saham nilai tukar rupiah, SBI, dan harga minyak dunia, memengaruhi harga saham (Artha, 2014; Setyawati et al., 2019). Pernyataan tersebut menunjukkan bahwa semakin banyak informasi makroekonomi yang didaptakan oleh sejumlah investor, semakin telitinya investor tersebut dalam menentukan saham-saham mana yang akan dibeli nantinya.

Beberapa hasil penelitian yang telah dilaksanakan sebelumnya mengenai aspek-aspek yang mempengaruhi harga saham yang telah dilakukan oleh Rochmah (2017) dan Munawarah (2015) yang hasil penelitian menyatakan bahwa analisis fundamental memberikan efek yang positif terhadap harga saham. Sedangkan hasil penelitian Tanasjah \& Moch (2015) dan Pringgabayu et al., (2020) menyatakan bahwa analisis fundamental tidak mempunyai efek apapun terhadap harga saham. Hasil penelitian tentang analisis teknikal yang telah dilakukan oleh (Tanasjah \& Moch, 2015) menyatakan bahwa tidak ada efek antara analisis teknikal terhadap harga saham.

Penelitian yang dilakukan oleh Tanasjah \& Moch (2015) tentang makroekonomi memperoleh hasil penelitian bahwa analasis makroekonomi memberikan efek yang positif 
kepada harga saham. Hal tersebut tidak sama dengan penelitian yang telah dilaksanakan oleh Julia \& Diyani (2015) dan Adanti (2017) yang menemukan hasil bahwa faktor makroekonomi memberikan nilai yang negatif dengan pergerakan harga.

Tujuan penelitian ini untuk menganalisis harga saham dengan menggunakan aspek fundamental, teknikal dan makro ekonomi. Dari penelitian ini diharapkan bermanfaat bagi akademisi dan khalayak masyarakat untuk memperhatikan aspek-aspek yang mempengaruhi harga saham dalam melakukan investasi terhadap saham suatu perusahaan.

\section{Metode Penelitian}

Penelitian ini merupakan penelitian deskriftif verifikatif dengan menggunakan datasekunder, yaitu mengambil data harga saham dan laporan keuangan perusahaan pada sektor energi yang tercatat di Bursa Efek Indonesia melalui web idx.go.id, periode 2015 - 2019. Sedangkan data tentang harga minyak dunia yang diperoleh dengan menelusuri website id.investing.com. Perubahan nilai tukar rupiah dan suku bunga Sertifikat Bank Indonesia (SBI) dapat ditelusuri pada website Bank Indonesia (www.bi.go.id).

Jumlah perusahaan dalam sektor energi di BEI berjumlah 71. Teknik pengambilan sampel menggunakan purposive random sampling dengan kriteria-kriteria: (1) perusahaan bersektor energi yang listing selama periode 2015-2019, (2) mengeluarkan laporan keuangan setiap tahun selama periode 2015-2019, (3) mempunyai fluktuasi harga saham, dan (4) harga saham tidak melebihi Rp. 20.000. Dengan menggunakan kriteria tersebut, maka perusahaan yang dianalisis berjumlah 21 perusahaan. Tabel 2 menunjukkan nama-nama perusahaan yang dijadikan sampel penelitian.

Tabel 2. Daftar Perusahaan sebagai Sampel Penelitian

\begin{tabular}{|c|c|c|c|c|c|}
\hline No. & $\begin{array}{c}\text { Nama } \\
\text { Perusahaan }\end{array}$ & $\begin{array}{l}\text { Kode } \\
\text { Saham }\end{array}$ & No. & Nama Perusahaan & $\begin{array}{l}\text { Kode } \\
\text { Saham }\end{array}$ \\
\hline 1 & $\begin{array}{l}\text { Adaro Energy } \\
\text { Tbk }\end{array}$ & ADRO & 12 & $\begin{array}{l}\text { Logindo } \\
\text { Samudramakmur Tbk. }\end{array}$ & LEAD \\
\hline 2 & AKR Corporindo & AKRA & 13 & $\begin{array}{l}\text { Mitrabahtera Segara } \\
\text { Sejati Tbk }\end{array}$ & MBSS \\
\hline 3 & $\begin{array}{l}\text { Pelayaran } \\
\text { Nasional Bina } \\
\text { Buana }\end{array}$ & BBRM & 14 & $\begin{array}{l}\text { Perusahaan Gas } \\
\text { Negara Tbk. }\end{array}$ & PGAS \\
\hline 4 & $\begin{array}{l}\text { Bayan } \\
\text { Resources Tbk. }\end{array}$ & BYAN & 15 & Bukit Asam Tbk. & PTBA \\
\hline 5 & $\begin{array}{l}\text { Buana Lintas } \\
\text { Lautan Tbk }\end{array}$ & BULL & 16 & Indo Straits Tbk. & PTIS \\
\hline 6 & $\begin{array}{l}\text { Delta Dunia } \\
\text { Makmur Tbk. }\end{array}$ & DOID & 17 & Petrosea Tbk. & PTRO \\
\hline 7 & Elnusa Tbk. & ELSA & 18 & Rukun Raharja Tbk. & RAJA \\
\hline 8 & $\begin{array}{l}\text { Humpuss } \\
\text { Intermoda } \\
\text { Transportasi }\end{array}$ & HITS & 19 & Soechi Lines Tbk. & $\mathrm{SOCl}$ \\
\hline 9 & $\begin{array}{l}\text { Harum Energy } \\
\text { Tbk. }\end{array}$ & HRUM & 20 & $\begin{array}{l}\text { TBS Energi Utama } \\
\text { Tbk. }\end{array}$ & TOBA \\
\hline 10 & $\begin{array}{l}\text { Indika Energy } \\
\text { Tbk. }\end{array}$ & INDY & 21 & $\begin{array}{l}\text { Wintermar Offshore } \\
\text { Marine Tbk }\end{array}$ & WINS \\
\hline 11 & $\begin{array}{l}\text { Resource Alam } \\
\text { Indonesia Tbk. }\end{array}$ & KKGI & & & \\
\hline
\end{tabular}


Tabel 3 menunjukkan variabel-variabel yang mempengaruhi harga saham pada sektor energi di Bursa Efek Indonesia.

Tabel 3. Variabel-variabel dalam Model Regresi

\begin{tabular}{|c|c|c|c|}
\hline Variabel & Sub Variabel & Definisi & $\begin{array}{l}\text { Skala } \\
\text { Ukur }\end{array}$ \\
\hline \multirow{4}{*}{$\begin{array}{l}\text { Analisis } \\
\text { Fundamental }\end{array}$} & $\begin{array}{l}\text { Return On Equity } \\
\text { (ROE) }\end{array}$ & $\begin{array}{l}\text { Perbandingan antara laba bersih setelah } \\
\text { pajak dengan ekuitas }\end{array}$ & Rasio \\
\hline & $\begin{array}{l}\text { Earning Per Share } \\
\text { (EPS) }\end{array}$ & $\begin{array}{l}\text { Perbandingan laba setelah pajak dengan } \\
\text { jumlah saham yangberedar }\end{array}$ & Rasio \\
\hline & Current Ratio (CR) & $\begin{array}{l}\text { Perbandingan antara aset lancardengan } \\
\text { utang lancar }\end{array}$ & Rasio \\
\hline & $\begin{array}{l}\text { Debt Equity to Ratio } \\
\text { (DER) }\end{array}$ & $\begin{array}{l}\text { Perbandingan antara total utang dengan } \\
\text { total aset }\end{array}$ & Rasio \\
\hline $\begin{array}{l}\text { Analisis } \\
\text { Teknikal }\end{array}$ & Tren saham & Pergerakan harga saham & Rasio \\
\hline \multirow{3}{*}{$\begin{array}{l}\text { Faktor-Faktor } \\
\text { Makroekonomi }\end{array}$} & $\begin{array}{l}\text { Tingkat Suku Bunga } \\
\text { Bank Indonesia }\end{array}$ & $\begin{array}{l}\text { Tingkat suku bunga yang ditentukan oleh } \\
\text { otoritas moneter untuk SBI yang } \\
\text { dikeluarkan }\end{array}$ & Rasio \\
\hline & Harga Minyak Dunia & $\begin{array}{l}\text { Standar harga West Texas Intermediate } \\
\text { (WTI) atau Brent }\end{array}$ & Rasio \\
\hline & Kurs Mata Uang & exchange rate & Rasio \\
\hline Harga Saham & $\begin{array}{l}\text { Harga penutupan } \\
\text { (closed price) }\end{array}$ & Harga yang menunjukkan nilai perusahaan & Rasio \\
\hline
\end{tabular}

Dalam penelitian ini digunakan data panel dengan 105 observasi. Penentuan model data panel yang digunakan,melalui beberapa pendekatan, yaitu pooled least squares/common effect model, fixed effect model dan random effect model.

Uji chow digunakan untuk mengevaluasi antara menggunakan Common Effect Model/CEM atau Fixed Effect Model/FEM. Jika hasil nilai statistik yang diberikan menunjukkan bahwa nilai $F<0.05$, maka model FEM dipilih. Uji lagrange multiplier digunakan untuk mengevaluasi antara menggunakan Random Effect Model/REM atau Pooled Least Squares/Common Effect Model. Jika hasil nilai statistik yang diberikan menunjukkan bahwa nilai both $<0.05$, maka model CEM dipilih. Sedangkan uji hausman digunakan untuk mengevaluasi antara menggunakan Random Effect Model/REM atau Fixed Effect Model/FEM Jika hasil nilai statistik yang diberikan menunjukkan bahwa nilai cross section random $>0.05$, maka model FEM dipilih.

Setelah menetapkan modelnya apakah pooled least squares/common effect model, fixed effect model atau random effect model, maka model harus sesuai dengan kaidah best linier unbias estimator (BLUE), sehingga uji normalitas, heteroskedastisitas, multikolineritas dan autokorelasi diperlukan.

Uji normalitas untuk mengetahui apakah data berdistribusi normal atau tidak. Apabila nilai statistik yang telah dihasilkan menunjukkan bahwa nilai $p>\alpha$ dan hitungan Jarque-Bera $<$ hitungan Chi Squere, maka data yang tersedia terdistibusi normal. Uji multikolinearitas digunakan untuk memastikan terdapat atau tidaknya korelasi yang tinggi atau sempurna di antara variabel bebas/independent yang membentuk model regresi data yang dipakai. Apabila hasil nilai statistik yang telah dihasilkan menunjukkan bahwa nilai korelasi antar variabel kurang $<0,80$, artinya penelitian ini tidak terjadi peristiwa gejala multikorlinear. Uji heteroskedastisitas 
untuk menguji apakah dalam model regresi terjadi ketidaksamaan variansi dari residual satu pengamatan ke pengamatan yang lain. Apabila hasil nilai statistik yang telah dihasilkan menunjukkan bahwa nilai $p$ atau probabilitas $>0,05$ berarti dapat diartikan tidak ada peristiwa heterokedastisitas. Uji autokorelasi untuk mendapatkan hasil apakah dalam model regresi ada korelasi antara residual satu observasinya dengan residual observasi lainnya. Apabila hasil nilai statistik yang telah dihasilkan menunjukkan bahwa nilai $\mathrm{dU}<$ Dublin Watson $<\mathrm{k}-\mathrm{dU}$, maka dapat dinyatakan bahwa penelitian yang telah dilakukan tidak terjadi gejala autokorelasi.

Model regresi berganda digunakan dalam penyelesaian permasalahan ini dengan dibantu oleh aplikasi Eviews 9 serta Microsoft Excel. Model penelitian ini dapat dirumuskan sebagai berikut:

$Y=a+b_{1} X_{1}+b_{2} X_{2}+b_{3} X_{3}+b_{4} X_{4}+b_{5} X_{5}+b_{6} X_{6}+b_{7} X_{7}+b_{8} X_{8}+e$

Dimana:

$\begin{array}{llll}\mathrm{Y} & =\text { Harga Saham } & \mathrm{X} 5 & =\text { Tren Harga Saham } \\ \mathrm{a} & =\text { Konstanta } & \mathrm{X} 6 & =\mathrm{B} \text { rate } \\ \mathrm{X} 1 & =\text { Return on Equity (ROE) } & \mathrm{X} 7 & =\text { Kurs Rupiah } \\ \mathrm{X} 2 & =\text { Earning Per Share (EPS) } & \mathrm{X} 8 & =\text { Harga Minyak Dunia } \\ \mathrm{X} 3 & =\text { Current Ratio (CR) } & \mathrm{e} & =\text { Variabel Penggangu } \\ \mathrm{X} 4 & =\text { Debt Equity to Ratio (DER) } & & \end{array}$

\section{Hasil dan Pembahasan}

\subsection{Spesifikasi Ekonometri}

Dari hasil uji Chow, uji Hausman, maupun uji lagrange multiplier, setiap variabel didapatkan model fixed effect. Sementara itu, uji F stat (uji global) dari setiap model adalah signifikan sehingga dapat disimpulkan bahwa model yang digunakan dalam penelitian ini dapat diterima dalam menggambarkan variabel dependennya.

Model regresi berganda sebagaimana ditunjukkan pada model (2), menggunakan model data panel fixed effect, sehingga kaidah BLUE (uji normalitas multikolinieritas, heteroskedastisitas, dan autokorelasi) tetap dilakukan.

Untuk uji normalitas ditunjukkan dalam diagram plot, seperti terlihat pada gambar 1.

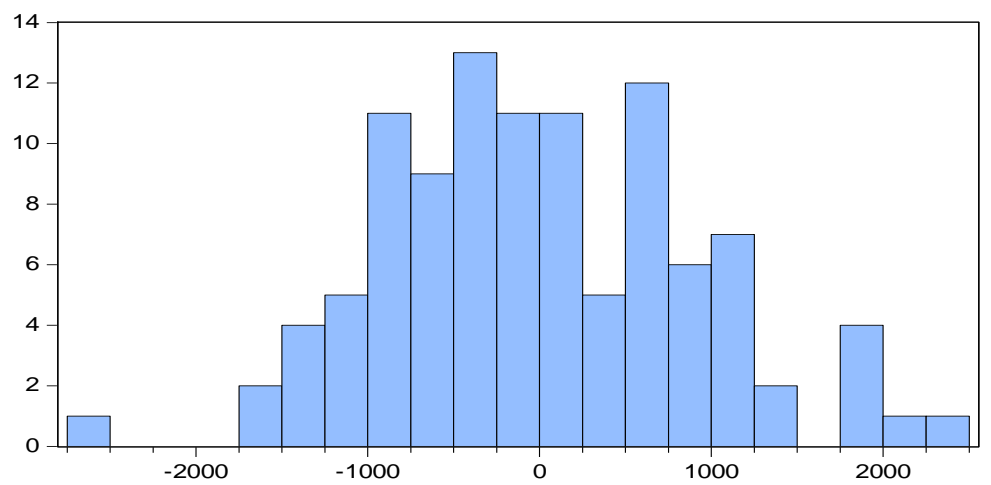

$\begin{array}{ll}\text { Series: Standardized Residuals } \\ \text { Sample 2015 } 2019 \\ \text { Observations } & 105 \\ \text { Mean } & -2.60 \mathrm{l}-14 \\ \text { Median } & -75.26125 \\ \text { Maximum } & 2476.212 \\ \text { Minimum } & -2559.828 \\ \text { Std. Dev. } & 909.2631 \\ \text { Skewness } & 0.252602 \\ \text { Kurtosis } & 3.039248 \\ & \\ \text { Jarque-Bera } & 1.123371 \\ \text { Probability } & 0.570247\end{array}$

Sumber: Hasil Pengolahan Data (2021)

Gambar1. Hasil Uji Normalitas 
Dari gambar 1 terlihat bahwa hasil uji normalitas diperoleh nilai $p(0.570247)>5 \%$ berarti $\mathrm{H}_{0}$ dapat diterima. Ini berarti bahwa residu mengalir secara normal. Selain itu model regresi yang digunakan terdistribusi normal.

Uji multikolinieritas dilakukan dengan mencari koefisien korelasi antara variable independent. Jika nilai korelasi parsial antara variable independent lebih besar dari 0,8 , berarti terindikasi adanya multikolinearitas (Gujarati \& Porter, 2010). Tabel 4 menunjukkan nilai korelasi parsial antara variable independent.

Tabel 4. Koefisien Korelasi Antar Variabel Independent

\begin{tabular}{ccccccccc}
\hline & $\mathrm{X} 1$ & $\mathrm{X} 2$ & $\mathrm{X} 3$ & $\mathrm{X} 4$ & $\mathrm{X} 5$ & $\mathrm{X} 6$ & $\mathrm{X} 7$ & $\mathrm{X} 8$ \\
\hline $\mathrm{X} 1$ & 1.000000 & 0.611496 & 0.106604 & -0.000348 & 0.092157 & -0.138130 & 0.072471 & 0.135324 \\
$\mathrm{X} 2$ & 0.611496 & 1.000000 & -0.029468 & -0.142503 & 0.144473 & -0.064502 & 0.162707 & 0.093914 \\
X3 & 0.106604 & -0.029468 & 1.000000 & -0.217084 & 0.025026 & -0.043130 & -0.020723 & 0.064958 \\
X4 & -0.000348 & -0.142503 & -0.217084 & 1.000000 & 0.055118 & 0.099240 & -0.009138 & -0.096347 \\
X5 & 0.092157 & 0.144473 & 0.025026 & 0.055118 & 1.000000 & -0.275590 & -0.354779 & 0.117175 \\
X6 & -0.138130 & -0.064502 & -0.043130 & 0.099240 & -0.275590 & 1.000000 & 0.413601 & -0.914356 \\
X7 & 0.072471 & 0.162707 & -0.020723 & -0.009138 & -0.354779 & 0.413601 & 1.000000 & -0.237743 \\
X8 & 0.135324 & 0.093914 & 0.064958 & -0.096347 & 0.117175 & -0.914356 & -0.237743 & 1.000000 \\
\hline \multicolumn{5}{l}{ Sumber: Hasil Pengolahan Data (2021) }
\end{tabular}

Hasil dari uji multikolinearitas diperoleh korelasi antar variabel kurang dari 0,80 , berarti tidak ada kejadian multikolinear dalam penelitian ini. Uji heteroskedasitas dilakukan dengan menggunakan Bruesch-Pagan/Cook and Weisberg's (Gujarati \& Porter, 2010). Tabel 4 menunjukkan uji Bruesch-Pagan/Cook and Weisberg's.

Tabel 4. Hasil Uji Heterokedastisitas

$\begin{array}{llll}\text { Cross-section fixed (dummy variables) } & & \\ & & & \\ \text { R-squared } & 0.666858 & \text { Mean dependent var } & 542.3362 \\ \text { Adjusted R-squared } & 0.544122 & \text { S.D. dependent var } & 950.8066 \\ \text { S.E. of regression } & 641.9730 & \text { Akaike info criterion } & 15.99612 \\ \text { Sum squared resid } & 31321824 & \text { Schwarz criterion } & 16.72912 \\ \text { Log likelihood } & -810.7965 & \text { Hannan-Quinn criter. } & 16.29315 \\ \text { F-statistic } & 5.433250 & \text { Durbin-Watson stat } & 3.206631 \\ \text { Prob(F-statistic) } & 0.000000 & & \end{array}$

Sumber: Hasil Pengolahan Data (2021)

Dari tabel 4 terlihat bahwa probabilitas antar variabel $>0,05$, dan dapat dinilai bahwa peristiwa heteroskedastisitas tidak terjadi. Sedang uji autokorelasi untuk menguji apakah dalam model regresi ada korelasi antara residual satu observasinya dengan residual observasi lainnya. Mengacu pada Tabel 4, maka didaptkan nilai 1,8483(dU) $<1,869968$ (Dublin Watson) $<6,15117(8-\mathrm{Du})$, dari nilai tersebut menandakan bahwa tidak ada gejala autokorelasi.

\subsection{Hasil Empiris}

Pada uji F statistik (uji goodness of fit), model ini signifikan karena nilai $p<0,05$, sehingga model dapat diterima karena ada kesesuaian antara data dengan model. Dengan R2 sebesar 90,03\%, artinya variasi harga saham dapat dijelaskan dengan variasi ROE, EPS, CR, 
tren harga saham, tingkat suku bunga SBI, kurs rupiah dan harga minyak dunia, sedangkan 9,97\% dijelaskan oleh variasi variabel lain, yang tidak terdapat dalam model. Tabel 5 menjelaskan ringkasan variabel yang diteliti.

Tabel 5. Ringkasan Variabel Penelitian

\begin{tabular}{|c|c|c|c|c|c|c|c|c|c|}
\hline Harga & - & 2.62 & - & - & 356.75 & -25790.37 & -0.027 & -0.003 & \\
\hline \multirow[t]{3}{*}{ saham= } & 358.89 & $\mathrm{EPS}^{\star * \star}$ & 11.67 & 42.71 & Tren & Tingkat & Kurs & Harga & \\
\hline & ROE & & $\mathrm{CR}$ & DER & harga & bunga & rupiah & minyak & \\
\hline & & & & & saham $^{\star * *}$ & $\left.\mathrm{SBI}\right|^{* * *}$ & & dunia*** & \\
\hline $\mathrm{se}=$ & 666.02 & 0.54 & 54.66 & 78.52 & 110.57 & 9662.33 & 0.132 & 0.00084 & \\
\hline \multirow[t]{2}{*}{$t=$} & -0.539 & 4.823 & - & - & 3,54 & -3.226 & -2.669 & -3.69120 & \\
\hline & & & 0.213 & 0.543 & & & & & \\
\hline Prob & 0.591 & 0,000 & 0.831 & 0.588 & 0.0019 & 0,049 & 0.841 & 0.0004 & $\mathrm{R} 2=0,903$ \\
\hline
\end{tabular}

Adapun persamaan regresi dari penelitian ini, sebagai berikut: Harga Saham $=-358,89$ ROE + 2,62 EPS - 11,67 CR - 42,71 DER + 356,75 TREN HARGASAHAM - 25790,37 TINGKAT BUNGA SBI - 0,027 KURS RUPIAH - 0,003 HARGA MINYAK DUNIA

Dari tabel 5 terlihat bahwa Earning Per Share (EPS), dan tren harga saham mempunyai pengaruh positif dan signifikan pada tingkat $\alpha=1 \%$ terhadap harga saham. Hal ini menunjukkan bahwa investor mempertimbangkan EPS dan tren harga saham dalam pengambilan keputusan untuk berinvestasi saham. Hasil penelitian tentang pengaruh positif antara EPS terhadap harga saham sesuai dengan penelitian yang dilakukan oleh Watung \& Ilat (2016) dan Santy (2017), sedangkan penelitian Rahmadewi (2018) menyatakan sebaliknya, bahwa EPS berpengaruh negatif terhadap harga saham.

Pengaruh positif antara tren harga saham terhadap harga saham juga sejalan dengan hasil penelitian yang dilakukan oleh Putri \& Mesrawati (2020). Hal ini menjukkan bahwa analisis teknikal dapat dijadikan acuan bagi investor dalam melakukan investasi saham.

Tingkat bunga SBI dan harga minyak dunia mempunyai pengaruh negatif dan signifikan pada tingkat $\alpha=1 \%$ terhadap harga saham. Dalam melakukan investasi, seorang investor akan mencari tingkat pengembalian yang paling tinggi, sehingga investor sangat mudah dapat mengalihkan dananya dari satu aset ke aset lainnya untuk mencari aset yang memberikan tingkat pengembalian yang lebih tinggi (Setyawati, I., Molina, M., Muhani, M., \& Huda, 2021). Apabila tingkat bunga SBI meningkat, maka investor akan menarik dananya dari kepemilikan saham untuk dialihkan ke SBI, demikian pula sebaliknya, sehingga antara tingkat bunga SBI mempunyai pengaruh negatif terhadap harga saham. Penelitian ini sejalan dengan penelitian Dodi Arif (2014).

Harga minyak dunia mempunyai pengaruh negatif dan signifikan terhadap harga saham. Lonjakan harga minyak dunia dapat mengakibatkan efek yang berbeda-beda terhadap harga saham. Untuk perusahaan yang bidang usahanya bukan pertambangan, Ionjakan harga 
minyak akan memberikan efek negatif, karena berdampak pada kenaikan biaya produksi yang akan mengakibatkan turunnya laba bersih dan secara tidak langsung menurunkan harga saham. Sedangkan pada perusahaan dengan bidang usaha pertambangan, lonjakan harga minyak memberikan efek positif pada kenaikan pendapatan perusahaan yang akan mengakibatkan naiknya laba bersih diperoleh kemudian secara tidak langsung harga saham naik. Penelitian ini tidak sejalan dengan penelitian yang dilakukan oleh Prasetiono (2010) dan Handiani (2014), di mana harga minyak dunia mempunyai pengaruh positif terhadap harga saham.

Return on equity (ROE), Current Ratio (CR), Debt to Equity Ratio (DER), dan kurs rupiah mempunyai pengaruh negatif tidak signifikan terhadap harga saham. Dengan demikian, sebagian analisis fundamental tidak dapat digunakan sebagai pengambilan keputusan investor dalam melakukan investasi.

Return on equity (ROE) berpengaruh negatif tidak signifikan terhadap harga saham. ROE merupakan rasio yang dijadikan indikator oleh investor dalam melakukan investasi, karena nilai ROE menunjukkan seberapa besar tingkat pengembalian yang diperoleh investor dari investasi yang ditanamkan di perusahaan. Mestinya, semakin besar ROE akan meningkatkan nilai perusahaan yang tercermin dari harga sahamnya. Hal ini kemungkinan disebabkan karena tingginya tingkat bunga SBI selama periode penelitian, sehingga investor cenderung menginvestasikan dananya di SBI dibandingkan di saham perusahaansektor energi dengan ROE yang lebih rendah. Penelitian ini tidak sejalan dengan penelitian Watung \& llat (2016), Wirajaya (2017), Rahmadewi (2018), Fahlevi et al.(2018) yang menyatakan bahwa ROE berpengaruh positif terhadap harga saham.

Current Ratio (CR) mempunyai pengaruh negatif tidak signifikan terhadap harga saham. CR merupakan kemampuan perusahaan dalam menyelesaikan utang jangka pendek dengan harta lancarnya, sehingga nilai $C R$ yang baik jika nilai harta lancarnya lebih besar dibandingkan dengan nilai utang lancarnya. Akan tetapi nilai $\mathrm{CR}$ yang terlalu tinggi mengindikasikan perusahaan mempunyai idle fund yang besar. Dengan demikian pengaruh negatif itu dapat menunjukkan 2 (dua) indikasi. Pertama, bahwa perusahaan sektor energi tidak mempu menyelesaikan utang jangka pendeknya yang telah jatuh tempo sedangkan indikasi kedua perusahaan terlalu banyak idle fund sehingga aset perusahaan tidak dapat menghasilkan pendapatan yang mengakibatkan nilai ROA rendah. Penelitian ini sejalan dengan penelitian Samsuar \& Akramunnas (2017), Wirajaya (2017) dan Rahmadewi (2018).

Debt to Equity Ratio (DER), dan kurs rupiah mempunyai pengaruh negatif tidak signifikan terhadap harga saham. DER mengindikasikan jumlah utang (jangka pendek dan jangka panjang) perusahaan yang dapat ditanggung dengan ekuitas yang dimiliki perusahaan. Semakin besar nilai DER membawa dampak penurunan kemampuan perusahaan dalam menyelesaikan utangnya, sehingga nilai DER yang semakin besar membuat investor khawatir menanamkan saham di perusahaan ini. Dengan demikian masuk akal jika pengaruh DER terhadap harga saham adalah negatif. Penelitian ini sejalan dengan penelitian yang dilakukan 
oleh Wirajaya (2017), sedangkan penelitian Samsuar \& Akramunnas (2017),menyatakan bahwa DER berpengaruh positif terhadap harga saham.

Kurs rupiah mempunyai pengaruh negatif tidak signifikan terhadap harga saham. Kurs mata uang asing merupakan nilai mata uang suatu negara yang dinyatakan dalam nilai mata uang negara lain. Contohnya kurs rupiah terhadap dolar AS menunjukkan jumlah nilai rupiah untuk ditukarkan dengan 1 dolar AS. Fluktuasi nilai kurs rupiah terhadap dolar AS mempunyai efek yang berbeda terhadap jenis saham yang diperdagangkan. Suatu saham perusahaan akan memperoleh dampak positif, sedangkan saham perusahaan lain terkena dampak negatif. Perusahaan yang memiliki utang dalam dolar pasti akan terkena dampak negatif jika terjadi kenaikan kurs USD terhadap rupiah, sedangkan perusahaan yang tidak berutang dalam bentuk dolar ataupun perusahaan yang melakukan kegiatan ekspor, menerima dampak positif atas kenaikan kurs USD. Penelitian ini sejalan dengan penelitian Prasetiono (2010), dan Setyawati et al. (2019).

\section{Kesimpulan}

Dalam penelitian ini ditemukan bahwa analisis fundamental yang terdiri dari variabel EPS, ROE, CE dan DER, tidak kesemuanya dapat dijadikan acuan investor dalam pengambilan keputusan berinvestasi. Hanya EPS yang mempunyai pengaruh positif dan signifikan, sedangkan ROE, $C R$, dan DER mempunyai pengaruh negatif tidak signifikan terhadap harga saham. Analisis teknikal yang terdiri dari berupa variabel tren harga saham mempunyai pengaruh positif dan signifikan terhadap harga saham, sehingga tren harga saham merupakan faktor yang penting bagi investor saham. Analisis makroekonomi yang terdiri dari variabel suku bunga SBI, harga minyak dunia, kurs rupiah terhadap dolar AS tidak kesemuanya dapat dijadikan acuan investor dalam pengambilan keputusan berinvestasi. Tingkat bunga SBI dan harga minyak dunia mempunyai pengaruh negatif dan signifikan, sedangkan kurs rupiah mempunyai pengaruh negatif tidak signifikan terhadap harga saham. Dari penelitian ini, maka sebaiknya seorang pimpinan perusahaan dapat menjaga keberlanjutan hidup perusahaan dengan membuat strategi yang efektif dalam meningkatkan harga saham. Nilai perusahaan tercermin dari harga saham, sedangkan investor melihat harga saham sebagai dasar keputusan investasi. Pimpinan perusahaan perlu juga memperhatikan faktor fundamental, teknikal dan makroekonomi dalam meningkatkan harga saham, di mana faktor makroekonomi merupakan faktor yang sulit dikontrol oleh perusahaan. Penelitian ini memiliki keterbatasan dalam variabel yang digunakan dalam analisis fundamental, teknikal dan makroekonomi, diharapkan penelitian selanjutnya dapat menambahkan dengan variabel lain yang belum terdapatdalam penelitian ini. Di samping itu, penelitian lanjutan juga dapat memperpanjang periode penelitian atau membandingkan kondisi sebelum dan setelah pandemi Covid19. Penelitian ini diharapkan dapat menjadi referensi tambahan dalam penyempurnaan penelitian selanjutnya. 


\section{Daftar Pustaka}

Adanti, W. A. (2017). Analisis Pengaruh Faktor Fundamental Makro Ekonomi terhadap Indeks Harga Saham Gabungan (IHSG). Jurnal IImiah Aset, 19(2), 161-172.

Artha, D. R. (2014). Analisis Fundamental, Teknikal Dan Makroekonomi. Jurnal Manajemen Dan Kewirausahaan, 16(2), 175-183. https://doi.org/10.9744/jmk.16.2.175

Dodi Arif. (2014). Pengaruh Produk Domestik Bruto, Jumlah Uang Beredar, Inflasi dan BI Rate terhadap Indeks Harga Saham Gabungan di Indonesia Periode 2007-2013. In Jurnal Ekonomi Bisnis (Vol. 19, Issue 3, pp. 63-77).

Fahlevi, R. R., Asmapane, S., \& Oktavianti, B. (2018). Pengaruh kinerja keuangan terhadap harga saham pada perusahaan perbankan yang terdaftar di bursa efek indonesia The effect of financial performance on stock prices on banking companies listed on the stock exchange of Indonesia. Akuntabel, 15(1), 39-48.

Gujarati, D. N., \& Porter, D. C. (2010). Essentials of Econometrics.

Handiani, S. (2014). Pengaruh harga emas dunia, harga minyak dunia dan nilai tukar dolar amerika/rupiah terhadap indeks harga saham gabungan pada periode 2008-2013. EJournal Graduate Unpar, 1(1).

Julia, T. T., \& Diyani, L. A. (2015). Pengaruh faktor fundamental keuangan dan makroekonomi terhadap harga saham. Jurnal Bisnis Dan Komunikasi, 2(2), 109-119, ISSN 2356-4385.

Munawarah. (n.d.). Pengaruh Analisis Fundamental Terhadap Harga Saham Pada Perusahaan Real Estate Dan Property. Jurnal Mutiara Akuntansi, 2(2), 73-82.

Prasetiono, D. W. (2010). Analisis Pengaruh Faktor Fundamental Ekonomi Makro Dan Harga Minyak Terhadap Saham Lq45 Dalam Jangka Pendek Dan Jangka Panjang. Journal of Indonesian Applied Economics, Vol. 4(1), 11-25.

Pringgabayu, D., De Keizer, H., \& Hardiyanti, S. D. (2020). Pengaruh Analisis Fundamental Terhadap Harga Saham Pada Industri Otomotif di Bursa Efek Indonesia Periode 20132017. Tirtayasa Ekonomika, 15(2), 210. https://doi.org/10.35448/jte.v15i2.7941

Putri, A. P., \& Mesrawati, M. (2020). Pengaruh Analisis Teknikal Terhadap Trend Pergerakan Harga Saham Perusahaan Subsektor Hotel Dan Restoran. EKUITAS (Jurnal Ekonomi Dan Keuangan), 3(3), 324-343. https://doi.org/10.24034/j25485024.y2019.v3.i3.4161

Rahmadewi, P. W. (2018). Pengaruh EPS, PER , CR , Dan ROE Terhadap Harga Saham Di Fakultas Ekonomi dan Bisnis Universitas Udayana , Bali , Indonesia. Manajem, 7(4), 2106-2133.

Rochmah, O. A. (2017). Analisis Pengaruh Faktor Fundamental dan Resiko Sistematik Terhadap Harga Saham. Jurnal Akutansi, 5(2).

Samsuar, T., \& Akramunnas. (2017). Pengaruh Faktor Fundamental dan Teknikal terhadap Harga Saham Industri Perhotelan yang Terdaftar di Bursa Efek Indonesia. Mushrafiyah, Jurnal Ekonomi, Keuangan Dan Perbankan Syariah, 1(1), 116-131.

Setiawan, E. P. (2020). Analisis Potensi Dan Risiko Investasi Cryptocurrency Di Indonesia. Jurnal Manajemen Teknologi, 19, 130-144.

Setyawati, I., Molina, M., Muhani, M., \& Huda, I. E. W. N. (2021). (2021). Kelayakan Investasi dengan Pendekatan Capital Asset Pricing Model Untuk Saham Kapitalisasi Terbesar di Bursa Efek Indonesia. Jurnal Kajian IImiah, 21(3), 329-340.

Setyawati, I., Sufyati, H. S., Kasim, M. Y., Meini, Z., \& Hardini, R. (2020). Does the Indonesian Capital Market Have Resistance During the Pandemic of Covid-19? ITALIENISCH, 11(2), 464-469.

Setyawati, I., Widyastuti, T., \& Suryati, A. (2019). Sharia Bank Resilience in Facing Macroeconomic Factors. https://doi.org/10.2991/icoi-19.2019.4

Statistik Bank Indonesia. (2020).

Statistik Pasar Modal. (2018).

Statistik Pasar Modal. (2021).

Tanasjah, S., \& Moch, S. (2015). Pada Harga Saham Sektor Properti.

Watung, R., \& Ilat, V. (2016). Pengaruh Return on Asset (Roa), Net Profit Margin (Npm), Dan Earning Per Share (Eps) Terhadap Harga Saham Pada Perusahaan Perbankan Di Bursa Efek Indonesia Periode 2011-2015. Jurnal Riset Ekonomi, Manajemen, Bisnis Dan Akuntansi, 4(2), 518-529. https://doi.org/10.35794/emba.v4i2.13108 
Wirajaya, I. G. A. (2017). Pengaruh Current Ratio, Debt To Equity Ratio dan Return On Assets pada Harga Saham. E-Jurnal Akuntansi, 21(2), 1317-1345. https://doi.org/10.24843/EJA.2017.v21.i02.p17 